\title{
Roman food not so fast
}

SIR - As a pioneer in the study of animal remains from archaeological sites, I counsel caution in concluding that a high proportion of pig bones indicates the decline of Rome into a fast-food empire (Nature 17 May, p.211). First, the bones indicate the proportions in which the different species were eaten rather than kept. Although in a peasant economy the two are probably the same, it is noteworthy that whereas the Cistercian monks kept thousands of sheep but relatively few cattle, 90 per cent of the medieval bone remains from Kirkstall Abbey were from cattle ${ }^{1}$.

Although it is true that the greatest proportion of pig bones from a Roman site in Britain (for comparison) was 26 per cent, the figures of 40 per cent and even 65 per cent pigs quoted by Hodges from Italy hardly indicate overwhelming predominance when one notes that cattle remains ranged up to 78 per cent and sheep remains up to 95 per cent on Roman sites, again in Britain ${ }^{2}$

The term "fast food" used by Hodges is used in a modern context for food preparation rather than for food production. Since the pig was a scavenger in the past, pork was certainly cheap to produce, but not "fast" or "short term" as Hodges implies, since until after the Middle Ages pigs were slow-maturing animals. If the production of pigmeat is relatively "fast" today (as a major component of "fast" or convenience foods) it is because pigs have been bred for early maturity and are fed concentrated cereal-based diets.

M.L. RYDER

Hill Farming Research Organisation, Bush Estate,

Penicuik, Midlothian EH26 OPY, UK

1. Ryder, M.L. Animal bones in Archaeology 2nd edn (Blackwell, Oxford, 1969).

2. Ryder, M.L. "Livestock" in The Agrarian History of England and Wales Vol. 1, Pt 1 (ed. Piggott, S.) (Cambridge University Press, 1981).

\section{Richard Hodges replies:}

SIR - Dr Ryder is making a mountain out of a molehill. My short review in Nature placed in a wider historical context a collection of recently published studies by archaeozoologists, in whom I have every confidence.

First, I made exactly the point (the main thrust of my note) that it was consumption of pig rather than any assumptions about production directly that made the data so historically interesting. I agree with him. However, I suspect his Kirkstall Abbey example is a poor illustration of his point, since I would imagine his high cattle bone is merely an indication of the sampling procedures (or lack of them) used when the site was excavated.

Second, I do not follow his point about Roman sites in Britain. To make such comparisons without considering historical and ecological contexts for the sites concerned is quite unscientific.

Third, I like the term "fast-food", suggested to me by your assistant editor. Of course, Ryder is strictly right. The term should have been qualified - and would have been in a long article - by precisely the comments he makes, effectively endorsing the reason for drawing attention to high pig numbers in the first place.

Department of Prehistory \&

RICHARD HODGES

Archaeology,

University of Sheffield,

Sheffield S10 2TN, UK

\section{Cancer incidence at Sellafield}

SIR - The investigation by Sir Douglas Black (see Nature 26 July, p.263) into the alleged increased incidence of cancer in West Cumbria usefully suggested what further research is needed, especially the measurement of radiation dose actually received and whether metabolic differences between children and adults alter the effects of radiation. However, on the

\begin{tabular}{ccrrr}
\hline $\begin{array}{c}\text { Ward } \\
\text { rank order }\end{array}$ & Cases & Children & $\begin{array}{c}\text { Poisson } \\
\text { probability }\end{array}$ & $\begin{array}{c}\text { Rate } \\
\text { per } 1,000\end{array}$ \\
\hline $1^{*}$ & 4 & 411 & 0.0001 & 9.73 \\
2 & 4 & 976 & 0.0032 & 4.09 \\
3 & 2 & 144 & 0.0036 & 13.88 \\
4 & 4 & 1,207 & 0.0068 & 3.31 \\
5 & 4 & 1,353 & 0.0100 & 2.95 \\
\hline
\end{tabular}

Top five wards ranked by Poisson probability for incidence of lymphoid malignancy in under 15 year olds, 1968-82 (from Craft et al. ${ }^{2}$ ).

*Seascale.

evidence already available, doubts must be raised about the report's judgement that the incidence of leukaemia in Seascale is "unusual but not unique".

The report examines the occurrence of lymphoid malignancy, in children under 15 , in the 765 electoral wards of Cumbria, from 1968 to 1982 . Incidence in the wards was ranked by rate per 1,000 . Seascale $(9.73 / 1,000)$ is ranked third. Although well above average $(0.61 / 1,000)$, Seascale appears to lie within the normal pattern of variation.

However, rate so measured is an uninformative index. As most wards have only 0 or 1 cases, all that is reflected in rate is ward size, which varies twenty-fold (from 100 to 2,000 ). A more appropriate measure is the cumulative Poisson probability. This gives the probability of occurrence in a ward of $0,1,2 \ldots$ cases, if the cases are randomly distributed in the region. The incidence seen in Seascale is $1.3 \times 10^{-4}$, which when ranked lies first (see table and ref. 2). This incidence is expected to occur once in a sample of 8,000 wards.

Even more disturbing are the two further cases of lymphoma registered in Seascale in 1983 (ref. 1). By updating the survey to
1983, the Poisson probability for such an occurrence falls to approximately $1.0 \times 10^{-6}$. This can only be described as unique, lying well beyond the expected variation.

The two simple points raised here must make the "qualified reassurance" given by the Black report less acceptable. Seascale has an extraordinarily high incidence of lymphoid malignancy. Its proximity to the Sellafield reprocessing plant, a potential source of mutagenic radiation, is disquieting.

ANDREW POMIANKOWSKI School of Biological Sciences,

University of Sussex,

Falmer,

Brighton, Sussex, UK

1. Report of the independent Advisory Group, Investization of the Possible Increased Incidence of Cancer in West Cumbria (HMSO, London, 1984)

2. Craft, A.W. Openshaw, S. \& Birch, J. Lancet ii, 96-97 (1984)

\section{Too many papers?}

SiR - For some years there has been talk of there being too many scientific journals but now it appears that there are too many papers. An informal sampling suggests that, in science and medicine, journals of reasonable status are experiencing an increase of around 10 per cent in submissions while editors in the area of whole organism biology or traditional life science disciplines have reported increases of up to 30 per cent, and even 50 per cent in the case of certain high status titles.

There are several possible explanations. (1) A demographic factor; as a result of the growth in tertiary education in the 1960 s, a large number of scientists are now in their most productive period and could be making a last effort to gain promotion. (2) Support of research in some areas, especially "soft" science, has been severely cut, heightening the struggle for grants. (3) Information technology has made it easier to store and process research data. This could be having an effect in astrophysics and geophysics in particular. (4) The decline in the publication of multi-author review volumes, resulting from library cutbacks, may have diverted longer review articles, or just the writing effort involved, towards refereed journals.

At present, smaller journals are being forced to restrict page budgets and there is the prospect of worthwhile if specialized papers going unpublished. Whatever the underlying reasons for the apparent increase in papers, the signs indicate a developing problem in the publication of research, especially in non-commercial areas such as ecology.

ROBERT CAMPBELL

Blackwell Scientific Publications,

Osney Mead,

Oxford OX2 OEL, UK

Department of Biology,

TiM HaLLIDAY

Open University,

Milton Keynes MK7 6AA, UK 